\title{
PENGARUH COLLABORATIVE LEARNING TERHADAP KEMAMPUAN MENULIS TEKS LAPORAN PERCOBAAN SISWA KELAS IX SMP NEGERI 24 PALEMBANG
}

\author{
Mulyati $^{1}$, Sari'ah $^{2}$ \\ Dosen Universitas Muhammadiyah Palembang', Guru SMP Negeri 24 Palembang ${ }^{2}$ \\ Jln. Jend. A.Yani 13 Ulu Palembang', Jln. Tegal Binangun Plaju Palembang ${ }^{2}$ \\ Sur-el: mulyatirozie@gmail.com¹, Sariahpalembang10@gmail.com²
}

Article info

Article history:

Received: $10 / 11 / 2019$

Revised : 16/11/2019

Accepted: 20/12/2019

Keywords:

Effect, Collaborative

Learning Model, Text

of Experimental

Report

Kata Kunci:

Pengaruh, Model

Collaborative

Learning, Teks

Laporan Pengamatan

Percobaan

\begin{abstract}
A B S T R A C T
The aim of this study was to determine the effect of collaborative learning models on students ability to write text of experimental report. The method used in this study is an experimental method through pretest and posttest. The population of this research was class IX students of SMP Negeri 24 Palembang, which totaled 147 students. The sample of this research was class IX students with 32 students. Data collection techniques used in this study were tests and questionnaires. Data analysis techniques used t-test. The results of this study can be concluded that the Collaborative Learning model take effect to the ability to write text of experimental report is significant, because it is proven $t$-score is greater than t-table at a significant level of $5 \%$ with $d b$ (free degrees) $t$-score $(12,711)>t$-table $(1,696)$. So, the hypothesis put forward is proven true.
\end{abstract}

Tujuan penelitian ini adalah untuk mengetahui pengaruh model collaborative learningterhadap kemampuan menulis teks laporan percobaan siswa.Metode yang digunakan dalam penelitian ini adalah metode eksperimen melalui pretes dan postes.Populasi penelitian ini adalah siswa kelas IX SMP Negeri 24 Palembang yang berjumlah 147 siswa.Sampel penelitian ini adalah siswa kelas IX yang berjumlah 32 siswa. Teknik pengumpulan data yang digunakan dalam penelitian ini adalah tes dan angket. Teknik analisis data yang digunakan adalah Uji-t. Hasil penelitian ini dapat disimpulkan bahwa model Collaborative Learning berpengaruh terhadap kemampuan menulis teks laporan percobaan tergolong signifikan, karena terbukti t-hitung lebih besar dari t-tabel pada taraf signifikan 5\% dengan db (derajat bebas) t-hitung (12.711) > t-table (1.696). Jadi, hipotesis yang dikemukakan terbukti kebenarannya. 


\section{PENDAHULUAN}

Nurjamal (2017), mengatakan bahwa keterampilan berbahasa terdiri atas keterampilan menyimak, keterampilan berbicara, keterampilan membaca, dan keterampilan menulis dalam Bahasa Indonesia yang baik dan benar. Salah satu keterampilan yang butuh perhatian lebih yaitu keterampilan menulis. Nurjamal (2017), mengatakan bahwa menulis tulisan juga merupakan media untuk melestarikan dan menyebarluasakan informasi dan ilmu pengetahuan. Kerampilan menulis tidak akan datang secara begitu saja tetapi harus melalui latihan praktik yang banyak dan teratur.

Pembelajaran Bahasa Indonesia dalam kurikulum 2013, lebih menekankan pada penulisan teks.Salah satu teks yang dipelajari adalah teks laporan percobaan.Pembelajaran teks laporan percobaan ini bertujuan untuk membantu peserta didik mengembangkan pengetahuan dan wawasan melalui kegiatan menulis teks laporan percobaan.Cahyaningsih (2014), mengatakan bahwa teks laporan percobaan adalah teks yang berisi penjabaran umum atau melaporkan sesuatu berupa hasil pengamatan (percobaan).Teks laporan percobaan ini diajarkan dan dipelajari di kelas IX SMP Negeri 24 Palembang. Berdasarkan pengamatan awal, diketahui bahwa sebagian besar hasil belajar siswa masih rendah (rata-rata nilai di bawah KKM), khususnya pada materi menulis teks laporan percobaan.

Upaya proses pengajaran ini untuk meningkatkan pembelajaran Bahasa Indonesia supaya lebih terampil menulis. Hal ini juga diharapkan kepada peserta didik untuk mengungkapkan pendapat melalui bahasa tulis serta mengajak siswa untuk bekerja sama suatu tim untuk memecahkan suatu masalah. Adapun salah satu model pembelajaran yang digunakan dalam pembelajaran menulis teks laporan percobaan ini adalah model pembelajaran Collaborative Learning (Pembelajaran Kolaborasi). Model Collaborative Learning mengajak siswa untuk bekerja sama. Adanya kerja sama berarti adanya interaksi dan pertukaran informasi. Jadi, pembelajaran kolaboratif adalah proses pembelajaran yang menekankan aktivitas belajar kelompok dan kerja sama dengan tujuan untuk meningkatkan kompetensi peserta didik menumbuhkan hubungan yang saling mendukung dan saling menghargai antar sesama. Hosnan (2014), mengatakan bahwa langkah pengenalan pembelajaran collaborative learning, sebagai berikut.

1) Para siswa dalam kelompok menetapkan tujuan belajar dan membagi tugas sendirisendiri.

2) Semua siswa dalam kelompok membaca, berdiskusi, dan menulis. 


\section{JURNAL ILMIAH \\ BINA EDUKASI \\ ISSN 1979-8598E-ISSN: 2655-8378 \\ http://journal.binadarma.ac.id/index.php/jurnalbinaedukasi \\ Vol. 12, No. 2, Desember 2019, 52 -- 61}

3) Kelompok kolaboratif bekerja secara bersinergi mengidentifikasi, mendemontrasikan, meneliti, menganalisis, dan memformulasikan jawaban-jawaban tugas atau masalah yang ditemukan sendiri.

4) Setelah kelompok kolaboratif menyepakati hasil pemecahan masalah, masing-masing siswa menulis laporan sendiri-sendiri secara lengkap.

5) Guru menunjuk salah satu kelompok secara acak (selanjutnya diupayakan agar semua kelompok dapat giliran ke depan) untuk melakukan presentasi hasil diskusi kelompok kolaboratifnya di depan kelas, siswa pada kelompok lain mengamati, mencermati, membandingkang hasil presentasi tersebut, dan menanggapi. Kegiatan ini dilakukan selama lebih kurang 20-30menit.

6) Masing-masing siswa dalam kelompok kolaboratif melakukan elaborasi, inferensi, dan revisi (bila diperlukan) terhadap laporan yang akan dikumpulkan.

7) Laporan masing-masing siswa terhadap tugas-tugas yang telah dikumpulkan, disusun per kelompok kolaboratif.

8) Laporan siswa dikoreksi, dikomentari, dinilai, dikembalikan pada pertemuan berikutnya, dan didiskusikan

Penelitian serupa juga pernah dilakukan oleh Sihite (2014), yaitu tentang pengaruh model pembelajaran kolaboratif (collaborative learning) terhadap kemampuan menulis teks eksposisi pada siswa kelas X SMA Negeri 1 Balige tahun pembelajaran 2013/2014. Kemudian Sri (2017), yaitu tentang pengaruh model pembelajaran kolaboratif (collaborative learning) terhadap kemampuan menulis teks eksposisi siswa kelas VII MTsN 1 Pesisir Selatan Kabupaten Pesisir Selatan. Perbedaan penelitian ini dengan penelitian sebelumnya, adalah subjek penelitan dan teks yang digunakan sebagai materi pembelajaran. Selain itu, penulis tertarik untuk melakukan penelitian di SMP Negeri 24 Palembang karena sekolah ini sudah terakreditasi A dan telah menerapkan Kurikulum 2013, khususnya pada pembelajaran Bahasa Indonesia. Selanjutnya, penelitian ini dapat dijadikan sebagai acuan untuk memudahkan peneliti lain yang melakukan penelitian serupa. Penulis menentukan kelas IX sebagai sampel dengan pertimbangan bahwa menulis teks laporan percobaan sudah dipelajari di kelas tersebut. Alasan penulis memilih judul “Pengaruh Model Pembelajaran Collaborative Learning terhadap Kemampuan Menulis Teks Laporan percobaan pada Siswa SMP Negeri 24 Palembang” karena SMP Negeri 24 Palembang belum menerapkan model pembelajaran Collaborative Learning pada pembelajaran menulis teks laporan percobaan.

Berdasarkan latar belakang yang penulis kemukakan di atas, maka rumusan masalah dalam penelitian ini adalah bagaimanakah pengaruh model pembelajaran collaborative learning terhadap kemampuan menulis teks laporan percobaan pada siswa kelas IX SMP Negeri 24 Palembang? 


\section{METODOLOGI PENELITIAN}

\subsection{Metode Penelitian}

Metode penelitian yang digunakan adalah penelitian eksperimen yang hanya dilakukan pada satu kelas eksprimen dengan menggunakan perbandingan tes awal (pretest) sebelum perlakuan dan tes akhir (posttest) setelah mendapat perlakuan model pembelajaran collaborative learning. Adapun desain eksperimen yang digunakan penulis yaitu desain eksperimen True Eksperimental Desain, yaitu jenis-jenis eksperimen yang dianggap sudah baik karena sudah memenuhi persyaratan.Adapun yang dimaksud dengan persyaratan eksperimen adalah pembanding test, dalam hal ini adanya tes awal (sebeluam perlakuan) dengan test akhir (setelah perlakuan) (Arikunto, 2013).Berdasarkan uraian tersebut, maka desain eksperimen adalah sebagai berikut.

\section{Keterangan:}

\section{E $01 \quad \mathrm{X} \quad \mathrm{O} 2$}

E : Kelas Eksperimen

O1 : Tes awal (Pretest)(tes awal)

O2 : Tes akhir (Prosttest)

$\mathrm{X} \quad$ : Perlakuan (Model Pembelajaran Collaborative Learning)

\subsection{Populasi dan Sampel}

Populasi penelitian ini adalah seluruh siswa kelas IX, yaitu kelas $\mathrm{IX}^{8}, \mathrm{IX}^{9}$ dan $\mathrm{IX}^{10}$ dengan jumlah 320 siswa.Teknik sampling yang digunakan dalam penelitian ini adalah teknik purposive sample.Menurut Arikunto (2013),purposive sample dilakukan dengan cara mengambil subjek bukan didasarkan atas strata, random, atau daerah tetapi dilaksanakan dengan syarat-syarat tertentu. Pengambilan sampel ini didasarkan dengan mempertimbangkan syaratsyarat berikut.

a) Pengambilan sampel harus didasari atas ciri-ciri, sifat atau karakteristik tertentu, yang merupakan ciri-ciri pokok populasi.

b) Subjek yang diambil sebagai sampel enar-benar merupakan subjek yang paling banyak mengandung ciri-ciri yang terdapat pada populasi (Arikunto, 2013). 


\section{JURNAL ILMIAH}

BINA EDUKASI

ISSN 1979-8598E-ISSN: 2655-8378

http://journal.binadarma.ac.id/index.php/jurnalbinaedukasi

Vol. 12, No. 2, Desember 2019, 52 -- 61

Berdasarkan pertimbangan di atas, maka sampel penelitian ini adalah siswa kelas IX $^{10}$ yang berjumlah tiga puluh empat (34) siswa.

\subsection{Teknik Pengumpulan Data}

Pengumpulan data dalam penelitian menggunakan teknik tes, angket dan wawancara. Instrumen tes digunakan untuk mengukur keterampilan siswa menulis teks laporan percobaan siswa kelas IX ${ }^{10}$ SMP Negeri 24 Palembang. Tes berbentuk essay.Aspek-aspek yang dinilai pada tes menulis teks laporan percobaan, yaitu (a) isi gagasan yang dikemukan, (b) organisasi isi, (c) tata bahasa, (d) gaya bahasa: pilihan struktur dan kosakata, (e) ejaan dan tata tulis.Angket digunakan sebagai pendukung data tes. Angket terdiri dari sepuluh butir pertanyaan dengan 4 pilihan jawaban untuk mendapatkan data tentang (a) proses belajar mengajar, (b) minat siswa, serta (c) faktor yang penghambat, dan (d) faktor penunjang dalam kegiatan belajar mengajar pada mata pelajaran Bahasa Indonesia serta dalam pengaruh model pembelajaran collaborative learning terhadap kemampuan menulis teks laporan percobaan. Wawancara terbuka dilakukan kepada guru Bahasa Indonesia sebagai responden.

\subsection{Teknik Analisis Data}

Data tes dianalisis menggunakan rubrik penilaian dengan kriteria penilaian menulis teks laporan percobaan tersebut dapat dilihat pada tabel di bawah ini.

Tabel 1. Penilaian Menulis Teks Laporan Percobaan

\begin{tabular}{llc}
\hline & Komponen yang Dinilai & Rentang Skor \\
\hline 1. & Isi gagasan yang dikemukakan & $13-30$ \\
2. & Organisasi isi & $7-20$ \\
3. & Tata bahasa & $5-25$ \\
4. & Gaya : pilihan struktur dan kosakata & $7-15$ \\
5. & Ejaan dan tata tulis & $3-10$ \\
\hline
\end{tabular}

Sumber : Burhan Nurgiyantoro (2017)

Penilaian kemampuan menulis teks laporan percobaan berdasarkan rubrik tersebut dianalisis menggunakan rumus sebagai berikut.

Nilai akhir $=\frac{\text { Skor yang diproleh }}{\text { Skor maksimal }} \times 100$

Data nilai pretes dan postes tersebut digunakan untuk mengukur pengaruh model pembelajaran Collaborative Learning terhadap kemampuan menulis teks laporan percobaan.Untuk mengetahui pengaruh penggunaan model pembelajaran Collaborative Learning digunakan Uji-T.Uji-T dilakukan dengan membandingkan t-hitung terhadap ttabel pada taraf signifikan 5\%. Uji-t dilakukan dengan menggunakan program SPSS. 
Data angket dan wawancara digunakan sebagai data pendukung dianalisis dengan mengklasifikasikan jawaban responden kemudian mendeskripsikan dan menarik kesimpulan.

\section{HASIL DAN PEMBAHASAN}

\subsection{Data Pretes dan Postes Menulis Teks Laporan Percobaan}

Berikut merupakan data nilai pretes dan postes yang diperoleh siswa kelas $\mathrm{IX}^{10}$ pada tes menulis teks laporan percobaan.

Tabel 2. Nilai Pretes dan Postes Kelas Eksperimen

\begin{tabular}{|c|c|c|c|c|c|}
\hline \multirow[t]{2}{*}{ No } & \multirow[t]{2}{*}{ Siswa } & \multicolumn{2}{|c|}{ Nilai } & \multirow{2}{*}{ (X2-X1) } & \multirow{2}{*}{$\left(\mathrm{X}^{2}\right)$} \\
\hline & & Pretes (X1) & Postes (X2) & & \\
\hline 1. & AS & 70 & 78 & 8 & 64 \\
\hline 2. & $\mathrm{AA}$ & 65 & 76 & 6 & 36 \\
\hline 3. & $\mathrm{AB}$ & 82 & 90 & 8 & 64 \\
\hline 4. & $\mathrm{AZ}$ & 61 & 76 & 15 & 225 \\
\hline 5. & Am & 78 & 90 & 12 & 144 \\
\hline 6. & ASy & 68 & 78 & 10 & 100 \\
\hline 7. & $\mathrm{AV}$ & 74 & 80 & 6 & 36 \\
\hline 8. & $\mathrm{AAj}$ & 65 & 76 & 11 & 121 \\
\hline 9. & $\mathrm{CP}$ & 85 & 90 & 5 & 25 \\
\hline 10. & $\mathrm{DN}$ & 70 & 77 & 7 & 49 \\
\hline 11. & $\mathrm{D}$ & 74 & 76 & 2 & 4 \\
\hline 12. & DF & 64 & 78 & 16 & 256 \\
\hline 13. & DA & 80 & 94 & 14 & 196 \\
\hline 14 & Des & 85 & 95 & 10 & 100 \\
\hline 15. & DK & 74 & 80 & 6 & 36 \\
\hline 16. & $\mathrm{Di}$ & 68 & 80 & 12 & 144 \\
\hline 17. & EA & 72 & 78 & 6 & 36 \\
\hline 18. & FR & 68 & 77 & 9 & 81 \\
\hline 19. & KK & 81 & 84 & 3 & 9 \\
\hline 20 & MAP & 68 & 78 & 10 & 100 \\
\hline 21. & MDT & 68 & 78 & 10 & 100 \\
\hline 22. & MPP & 65 & 77 & 12 & 144 \\
\hline 23. & No & 70 & 78 & 8 & 64 \\
\hline 24. & PA & 72 & 73 & 1 & 1 \\
\hline 25. & PS & 74 & 90 & 16 & 256 \\
\hline 26. & PW & 75 & 80 & 5 & 25 \\
\hline 27. & PZ & 70 & 76 & 6 & 6 \\
\hline 28. & $\mathrm{RJ}$ & 70 & 72 & 2 & 4 \\
\hline 29. & SA & 70 & 80 & 10 & 100 \\
\hline 30. & Sil & 70 & 78 & 8 & 64 \\
\hline 31. & SDW & 64 & 78 & 14 & 196 \\
\hline 32. & $\mathrm{Ye}$ & 68 & 78 & 10 & 100 \\
\hline \multicolumn{2}{|c|}{ Jumlah } & 2288 & 2569 & 283 & 2971 \\
\hline \multicolumn{2}{|c|}{ Mean } & 71.5 & 80.28 & 8.84 & \\
\hline
\end{tabular}




\section{JURNAL ILMIAH}

BINA EDUKASI

ISSN 1979-8598E-ISSN: 2655-8378

http://journal.binadarma.ac.id/index.php/jurnalbinaedukasi

Vol. 12, No. 2, Desember 2019, 52 -- 61

Berdasarkan data pada tabel 2 di atas diketahui bahwa dari hasil pretessiswa yang memperoleh nilai $75-100$, yaitu nilai $75-85$ berjumlah 7 orang $(21,8 \%)$ dan siswa yang memperoleh nilai kurang dari 75 berjumlah 25 orang $(78,1 \%)$. Sehingga nilai rata-rata prestest 71,5 .

Dari hasil postes,siswa yang memperoleh nilai $75-100$ berjumlah 30 orang $(93,7 \%)$ dan siswa yang memperoleh nilai kurang dari 75 berjumlah 2 orang $(6,2 \%)$. Sehingga nilai rata-rata postessebesar 80,28> 75 (nilai kriteria ketuntasan minimum [KKM]).

\subsection{Hasil Uji-T}

Berdasarkan hasil uji-t menggunakan Paired Samples Test diperoleh hasil sebagai berikut.

Tabel 3. Paired Sample Test

\begin{tabular}{|c|c|c|c|c|c|c|c|c|c|}
\hline & & & & aired Differ & nces & & & & \\
\hline & & & St & Std. Error & $\begin{array}{l}95 \% \text { Confide } \\
\text { of the Di }\end{array}$ & $\begin{array}{l}\text { e Interval } \\
\text { rence }\end{array}$ & & & Sig. (2- \\
\hline & & Mean & Deviation & Mean & Lower & Upper & $\mathrm{t}$ & $\mathrm{df}$ & tailed) \\
\hline Pair 1 & $\begin{array}{l}\text { Pre - } \\
\text { Post }\end{array}$ & -8.781 & 3.908 & .691 & -10.190 & -7.372 & -12.711 & 31 & .000 \\
\hline
\end{tabular}

Berdasarkan perbandingan hasil uji-t diatas, dapat diketahui bahwa t-hitung $(12,711)>t-$ tabel (1.696) maka hipotesis penelitian diterima. Dengan demikian, dapat disimpulkan bahwa ada pengaruh model collaborative learning terhadap kemampuan menulis teks laporan percobaan pada siswa kelas IX $^{10}$ di SMP Negeri 24 Palembang. Untuk lebih jelasnya dapat dilihat pada grafik hasil perbandingan nilai pretes dan postes berikut ini.

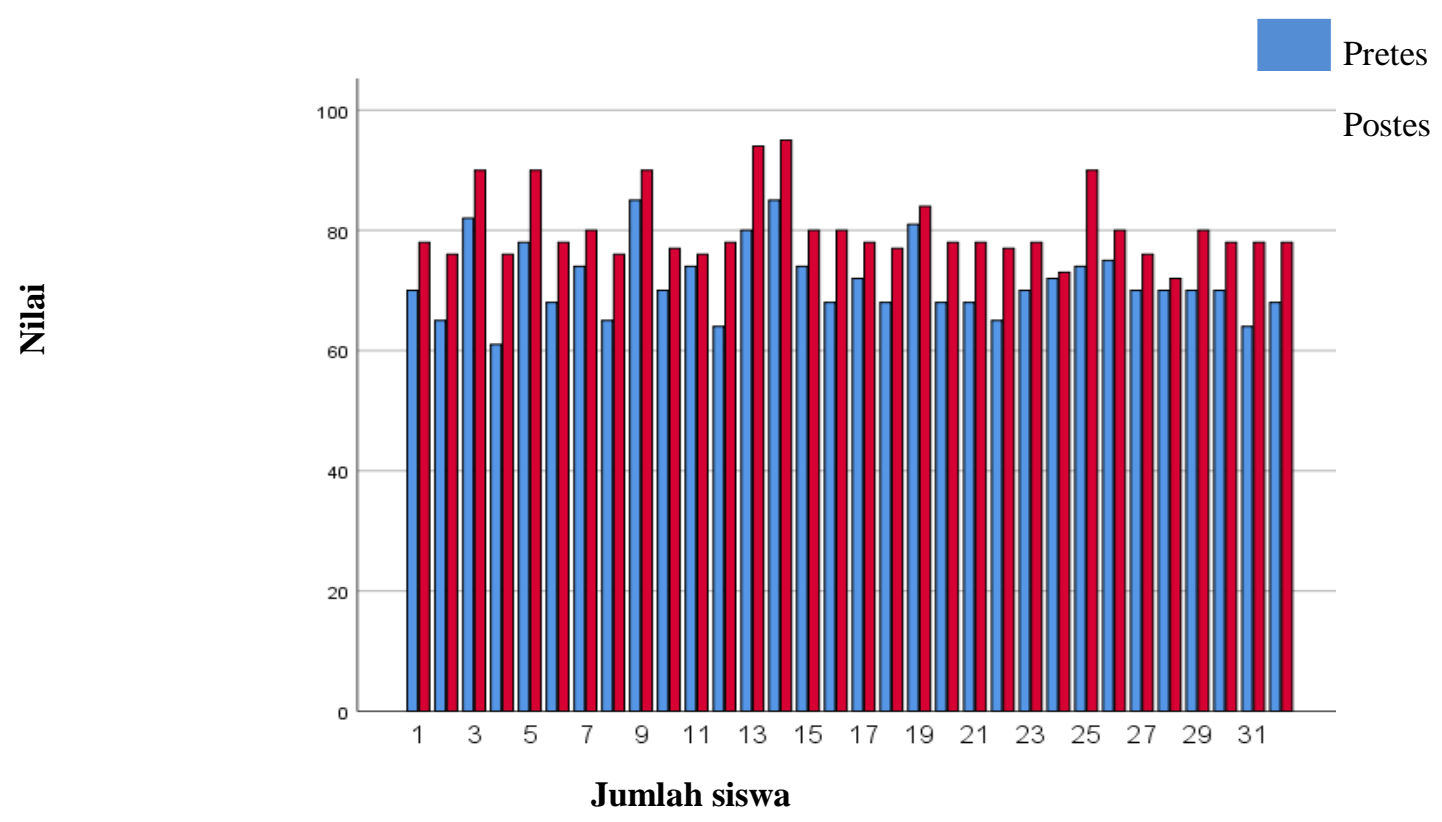

Gambar 1. Nilai Pretes dan Postes Menulis Teks Laporan Percobaan 


\section{JURNAL ILMIAH \\ BINA EDUKASI \\ ISSN 1979-8598E-ISSN: 2655-8378 \\ http://journal.binadarma.ac.id/index.php/jurnalbinaedukasi \\ Vol. 12, No. 2, Desember 2019, 52 -- 61}

Berdasarkan hasil deskripsi data angket yang direspon oleh siswa dan wawancara yang dilakukan dengan guru Bahasa Indonesia tentang kegiatan pembelajaran dan materi pembelajaran, yaitu teks laporan percobaan. Pertama, pada proses pembelajaran di kelas: (1) setiap kegiatan pembelajaran diawali dengan kegiatan apersepsi, yaitu guru selalu mengulas kembali materi yang diberikan pada sebelumnya, menghubungkan materi yang telah dipelajari dengan materi yang akan dipelajari, menjelaskan tujuan pembelajaran dan indikator yang harus dicapai oleh siswa; (2) model pembelajaran, seperti: ceramah, tanya-jawab; dan latihan yang kurang efektif dan monoton digunakan dalam kegiatan pembelajaran; (3) guru masih sebagai pusat pembelajaran bukan fasilitator karena siswa yang mengalami kesulitan bertanya pada guru; (4) setiap akhir kegiatan pembelajaran, siswa selalu diberi latihan. Kedua, materi pembelajaran, yaitu: (1) guru pernah mengajarkan tentang teks laporan percobaan; (2) siswa menyukai pelajaran bahasa Indonesia dan teks laporan percobaan; (3) menurut siswa, teks laporan percobaan mudah dipelajari.

Setelah kegiatan pembelajaran menggunakan model CollaborativeLearning, dilakukan wawancara kembali dengan siswa dan guru. Dari hasil wawancara, diketahui bahwa (1) siswa menyukai kegiatan pembelajaran menggunakan model Collaborative Learning karena menyenangkan karena mereka tidak hanya mendengarkan penjelasan guru; (2) siswa lebih banyak mencari jawaban sendiri jika mendapatkan pertanyaan tentan teks laporan percobaan dengan membaca buku atau sumber belajar lain; (3) guru membuktikan bahwa dengan menerapkan model Collaborative Learning menjadikan siswa sebagai pusat belajar sehingga sangat memudahkan guru dalam proses pembelajaran; (4) guru membuktikan bahwa model Collaborative Learning sangat efektif dan berpengaruh dalam meningkatkan hasil belajar siswa, khususnya dalam pembelajaran teks laporan percobaan.

Berdasarkan hasil penelitian yang membuktikan bahwa model pembelajaran Collaborative Learning memberikan pengaruh dalam meningkatkan kemampuan menulis teks laporan percobaan pada siswa kelas IX ${ }^{10}$ SMP Negeri 24 Palembang.Hal tersebut terlihat dari hasil uji-t yang telah dilakukan pada nilai pretes dan postes yang telah diperoleh oleh siswa. Dari hasil uji-t diperoleh nilai t-hitung, yaitu 12,711 lebih besar dari t-tabel pada df 31, yaitu 1,696. Hal tersebut menunjukkan bahwa hipotesis peneliti bahwa model Collaborative Learning berpengaruh terhadap peningkatan kemampuan menulis teks laporan percobaan siswa kelas $\mathrm{IX}^{10}$.

Hasil penelitian serupa juga dibuktikan oleh Sihite (2014) yang menerapkan model Collaborative Learning dibandingkan dengan model pembelajaran ekspositori dalam pembelajaran menulis teks eksposisi, yaitu nilai rata-rata siswa saat menggunakan model ekspositori adalah 74, 37, kemudian setelah menggunakan model collaborative learning, nilai 


\section{JURNAL ILMIAH \\ BINA EDUKASI \\ ISSN 1979-8598E-ISSN: 2655-8378 \\ http://journal.binadarma.ac.id/index.php/jurnalbinaedukasi \\ Vol. 12, No. 2, Desember 2019, 52 -- 61}

rata-rata siswa adalah 78,75. Hasil tersebut juga dibuktikan dengan hasil uji-t, yaitu t-hitung $>$ ttabel, yaitu 2,023>2,00. Sri (2017) juga membuktikan hal sama, bahwa model collaborative learning berpengaruh terhadap peningkatan kemampuan menulis teks eksposisi. Hasil penelitian Sri (2017) menunjukkan bahwa t-hitung > t-tabel, yaitu 9,90>1,71.

Selain hasil dari data primer, berdasarkan data sekunder yaitu respon siswa dan guru yang diperoleh dari angket dan wawancara juga menunjukkan hasil yang sesuai dengan hasil dari data primer.Berdasarkan respon siswa dan guru, penerapan model collaborative learning membuat kegiatan pembelajaran menjadi lebih menarik dan menyenangkan, serta berpusat pada siswa.Sehingga, siswa lebih memahami kegiatan menulis teks laporan percobaan.

\section{SIMPULAN}

Berdasarkan data nilai pretes dan postes yang diperoleh siswa, yaitu nilai rata-rata pretes sebesar 71.5 dan postes sebesar 80.28 terlihat adanya peningkatan kemampuan menulis teks laporan percobaan. Kemudian, data tersebut juga diuji dengan uji-t yang menunjukkan hasil yang sama, yaitu t-hitung > t-tabel $(12,711>1.696)$. Dengan demikian, hipotesis yang dikemukakan peneliti, yaitu "model pembelajaran Collaborative Learning berpengaruh dalam keterampilan menulis teks laporan percobaan terbukti dan dapat diterima kebenarannya. Data tersebut juga didukung dengan hasil dari data sekunder, yaitu respon siswa dan guru yang diperoleh dari angket dan wawancara. Berdasarkan respon siswa dan guru, tentang kegiatan pembelajaran dan materi kegiatan diketahui bahwa (1) kegiatan pembelajaran menyenangkan dan menarik dibandingkan kegiatan pembelajaran sebelum menggunakan model collaborative learning, karena kegiatan pembelajaran berpusat pada siswa bukan guru sehingga siswa lebih aktif; (2) materi teks laporan percobaan adalah materi yang menarik dan mudah dipelajari.

Setelah melakukan penelitian ini, peneliti berharap supaya (1) siswa tetap semangat belajar dan menambah pengetahuan tentang teks-teks bahasa Indonesia, serta meningkatkan prestasi belajar; (2) guru-guru pengajar, baik pengajar bahasa Indonesia maupun pengajar mata pelajaran lain untuk kreatif menggunakan model, metode, atau strategi pembelajaran yang sesuai dengan materi pembelajaran sehingga kegiatan pembelajaran menjadi lebih menarik bagi siswa dan mudah bagi guru; (3) pihak sekolah juga mendukung efektivitas kegiatan belajar mengajar dengan menyediakan fasilitas belajar yang baik; (4) peneliti lanjutan dapat melakukan penelitian yang lebih lanjut dengan membandingkan model collaborative learning dengan model pembelajaran lainnya atau menggunakan model collaborative learning pada materi lain yang sesuai. 


\section{DAFTAR PUSTAKA}

Arikunto, Suharsimi. 2013. Prosedur Penelitian Suatu Praktik. Jakarta: Rineka Cipta.

Cahyaningsih.2014. Pengertian Teks Observasi dan Prosedur. http://aisyahcahyaningsih4.blogspot.com/2014/12/pengertian-teks-observasi-teksprosedur.html?m=1. Diunduh tanggal 21 Maret 2019.

Hosnan. 2014. Pendekatan Saintifik dan Kontekstual dalam Pembelajaran Abad 21 Kunci Sukses Implementasi Kurikulum 2013. Bogor: Ghalia Indonesia.

Nurgiyantoro, Burhan. 2017. Penilaian Pembelajaran Bahasa Berbasis Kompetensi: Edisi Kedua. Yogyakarta: Fakultas Ekonomika dan Bisnis UGM.

Nurjamal, Daeng dkk. 2017. Terampil Berbahasa. Bandung: Alfabeta.

Sihite, Pitra. 2014. Pengaruh Model Pembelajaran Kolaboratif (Collaborative Learning) Terhadap Kemampuan Menulis Teks Eksposisi Siswa Kelas X SMA Negeri 1 Balige Tahun Pembelajaran 2013/2014. Jurnal Bahasa, 3 (3).https://doi.org/10.24114/kjb.v3i3.1634. Diunduh tanggal 21 Maret 2019.

Sri, Rahayu. 2017. Pengaruh Model Pembelajaran Kolaboratif (CollaborativeLearning) terhadap Kemampuan Menulis Teks Eksposisi Siswa Kelas VII MTsN 1 Pesisir Selatan Kabupaten Pesisir Selatan. Skripsi tidak Dipublikasikan. Sumatera Barat: STKIP PGRI. 